\title{
Comparison of pneumococcal colonization density among healthy children and children with respiratory symptoms using real time PCR (RT-PCR)
}

G Vidanapathirana ${ }^{1}$, A L S K Angulmaduwa² ${ }^{2}$ T S Munasinghe ${ }^{3}$, EW M A Ekanayake ${ }^{2}$, P Harasgama², ST Kudagammana ${ }^{3}$, B N Dissanayake ${ }^{2}$ and L V C Liyanapathirana ${ }^{2^{*}}$

\begin{abstract}
Background: Nasopharyngeal colonization is considered a necessary step in the initiation of pneumococcal diseases. Real time PCR (RT-PCR) is an alternative approach for the identification and quantification of pneumococci directly from samples.

Objectives: To compare pneumococcal detection rates using culture-based method versus RT-PCR direct detection and to quantify pneumococcal colonization in two study cohorts (healthy children and hospitalized children with respiratory symptoms) using quantitation through RT-PCR.

Methodology: A total of 101 nasopharyngeal swabs (NPS) from healthy children and 183 NPSs from hospitalized children with respiratory symptoms were included in the study. None of the children were vaccinated. All children were between 2 months to 2 years. In parallel to routine culture and identification, a RT-PCR assay targeting the lytA gene was done.
\end{abstract}

Results: Considering all 284 samples tested, colonization rate by conventional culture was $41.2 \%(n=117)$ while positive colonization using RT-PCR was $43.7 \%(n=124)$. The colonization rate detected by RT-PCR in the healthy cohort was $33.7 \%(n=34)$ and it was $49.2 \%(n=90)$ in the hospitalized cohort. It was $37.6 \%(n=38)$ and $43.2 \%(n=79)$ for the two cohorts by culture. The mean Cq value for the healthy cohort is 29.61 (SD 2.85) and 28.93 (SD 3.62) for the hospitalized cohort.

With the standard curve obtained from amplifying a dilution series of control DNA, the mean amount of genomic DNA copy numbers detected in children with respiratory symptoms was log10 7.49 (SD 1.07) while it was log 107.30 (SD 0.23) in healthy children and the difference was not statistically significant.

Conclusions: The overall colonization rate was higher when detected using RT-PCR compared to culture. However, it was lower in the healthy group when detected with RT-PCR compared to culture. Even though there was a higher detection of pneumococcal colonization density in children with respiratory symptoms, this was not significantly

\footnotetext{
*Correspondence: veranjacl@yahoo.com; veranjacl@pdn.ac.lk

${ }^{2}$ Department of Microbiology, Faculty of Medicine, University

of Peradeniya, Kandy, Sri Lanka

Full list of author information is available at the end of the article
}

(C) The Author(s) 2022. Open Access This article is licensed under a Creative Commons Attribution 4.0 International License, which permits use, sharing, adaptation, distribution and reproduction in any medium or format, as long as you give appropriate credit to the original author(s) and the source, provide a link to the Creative Commons licence, and indicate if changes were made. The images or other third party material in this article are included in the article's Creative Commons licence, unless indicated otherwise in a credit line to the material. If material is not included in the article's Creative Commons licence and your intended use is not permitted by statutory regulation or exceeds the permitted use, you will need to obtain permission directly from the copyright holder. To view a copy of this licence, visit http://creativecommons.org/licenses/by/4.0/. The Creative Commons Public Domain Dedication waiver (http://creativeco mmons.org/publicdomain/zero/1.0/) applies to the data made available in this article, unless otherwise stated in a credit line to the data. 
higher unlike many previous studies. Therefore, the use of RT-PCR to detect pneumococcal colonization needs further evaluation with careful analysis of interpretation and confounders.

Keywords: Children, Colonization, Culture, Pneumococci, RT-PCR

\section{Introduction}

Streptococcus pneumoniae or pneumococcus is a pathogenic bacterium which can cause a variety of diseases ranging from non-invasive diseases such as otitis media, sinusitis to invasive diseases including pneumonia, meningitis, and sepsis. According to the World Health Organization (WHO), pneumococcal diseases were responsible for an estimated 317,300 pediatric deaths in 2015 [1]. Nasopharyngeal colonization of pneumococci has been identified as a prerequisite for the initiation pneumococcal disease and transmission of pneumococci [2]. Pneumococcal colonization rates differ globally according with socioeconomic factors and age [3]. It is highest among children below the age of 5 years [4]. In this age group too, it is found to vary between countries [4-8].

Laboratory identification and typing of pneumococci is performed using conventional methods based on phenotypic characteristics of pneumococci, serological tests and the molecular based techniques. The conventional method of identifying Streptococcus pneumoniae is through culture and detection of optochin sensitivity and bile solubility in presumptively identified isolates [9]. However, attributing aetiology is difficult, particularly when isolates are from nonsterile sites, where pneumococci may be found as part of the normal flora. This is confounded by identifying isolates that express different phenotypic characteristics. According to the published data, Deoxycholate solubility (Bile solubility test) has been associated with a sensitivity of $98 \%$ and a specificity of $100 \%$. However, pneumococcal isolates that are bile insoluble have also been reported [10].

Identification of pneumococcal aetiology of infections can be difficult since pneumococci are found as normal flora in children. Several studies have reported that high pneumococcal density in the nasopharynx is associated with pneumonia in children $[11,12]$ in addition; colonization with multiple pneumococcal serotypes is common in children in low- and middle-income countries [13].

There are only a few published data on quantitative analysis of pneumococcal colonizing density in children. A multicenter study conducted in Bangladesh, the Gambia, Kenya, Mali, South Africa, Thailand, and Zambia to find the density of upper respiratory colonization with Streptococcus pneumoniae among children less than 5 years, hospitalized with severe pneumonia revealed an association between pneumococcal colonization density and microbiologically confirmed pneumococcal pneumonia [14]. There are other similar studies which focused on the pneumococcal colonizing density and the prevalence of upper respiratory tract illnesses in children $[12,15,16]$. In addition to that, some studies have compared the pneumococcal densities in children before and after the implementation of pneumococcal conjugate vaccine $[17,18]$. However, many of these studies have been done in well controlled matched groups than in real world, clinical settings.

The main aim of the present study was to evaluate the pneumococcal colonizing density in healthy children and hospitalized children with respiratory symptoms using RT-PCR, in a vaccine naïve population. Further, comparison of pneumococcal detection rates using culture-based method versus RT-PCR direct detection was also done. We also aimed to see if serotyping can be done directly from extracted samples as this gives the additional advantage of identifying co-colonization, with the comparatively less expensive conventional PCR.

\section{Methodology}

For this study, we used a sub group of participants of a larger study. For the samples used for this analysis both culture based and RT-PCR based methods were used to identify pneumococcal colonization [19]. We selected samples taken from 101 healthy subjects between 2 months and 2 years ( 24 months) of age attending immunization clinics and 183 children being hospitalized with respiratory symptoms (cough, runny nose, difficulty in breathing, with or without fever as documented in the medical chart) at Teaching Hospital Peradeniya, Sri Lanka from October 2017-November 2018 for this sub-analysis. Samples were selected from the original 900 samples randomly [19]. These nasopharyngeal swabs were collected using an age-appropriate nylon tipped flocked swab (Hydraflock_, Hardy Diagnostics, U.S.A). NPS was immediately placed in a sterile screw-capped tube with STGG medium, transported to the laboratory and stored at $-80{ }^{\circ} \mathrm{C}$ till testing. Samples from the hospitalized group were collected within $48 \mathrm{~h}$ of hospitalization.

Participants were recruited after obtaining informed written consent from a guardian. Ethical approval for this study has been obtained from the Ethics Review Committee of Faculty of Medicine University of Peradeniya, Sri Lanka (2016/EC/63). None of the study participants were vaccinated. 


\section{Quantification of pneumococci}

An aliquot of randomly selected samples $(n=101$ from the healthy carriage group and $n=183$ from the samples collected from hospitalized children), were used for this component of the study. QIAamp ${ }^{\circledR}$ DNA mini kit (Qiagen) was used to extract DNA from the STGG aliquoted. Thawed samples were mixed with $0.1 \%$ sodium deoxycholate incubated for $1 \mathrm{~h}$ at $37^{\circ} \mathrm{C}$ before following manufacturer's instructions for the rest of the procedure [20].

Real time PCR was performed as previously described by Carvalho et al. [21]. Protocol was followed as given in the CDC Streptococcus lab protocol section using Promega GoTaq ${ }^{\circledR}$ Probe RT-PCR master mix [22].

As positive control, genomic DNA extracted from Streptococcus pneumoniae ATCC 49,619 was used. This DNA was quantified using Nanodrop and a tenfold dilution series was prepared. Each dilution was run in duplicate. Cq value of the control dilution series was used for identification of PCR efficiency as well as to quantify the DNA concentration [23].

\section{Semi quantitative culture method}

All samples were thawed, vortexed, and processed microbiologically as recommended by the WHO pneumococcal carriage working group [24]. Samples were plated on quality-controlled sheep blood agar (SBA) and incubated at $37{ }^{\circ} \mathrm{C}$ in $5 \%$ carbon dioxide. Plates were incubated for $48 \mathrm{~h}$ before discarding. Alpha hemolytic colonies were purified and pneumococci were identified by optochin sensitivity (incubated at $5 \% \mathrm{CO} 2$ ) and bile solubility testing. Confirmed pneumococcal isolates were stored in STGG at $-80^{\circ} \mathrm{C}$.
Semi-quantitative colony count was evaluated according to the growth of pneumococci along the streak lines.

Growth of alpha haemolytic colonies on the SBA plate was quantified as scanty, moderate and heavy according to the scheme given in Fig. 1.

\section{Direct detection of pneumococcal serotypes}

An attempt was made to detect co-colonization of different serotypes using the samples that tested positive for the lytA real time PCR. Direct Serotyping of the pneumococci in nasopharyngeal samples was performed using the sequential multiplex PCR protocol recommended by the CDC, Altanta [25]. However, only conventional multiplex-PCR was performed. As the multiplex PCRs failed to yield the cps band in many of these samples, a single conventional PCR for cps locus was done for those samples. In addition, single PCR was run for serogroup 6 and serotype $19 \mathrm{~F}$ in the samples that tested positive for $c p s$ by conventional PCR.

\section{Results}

Pneumococcal colonization rates and densities

A total of 284 nasopharyngeal swabs were tested with RT-PCR. 101 of the samples were from healthy children while 183 were from hospitalized children. RT-PCR positivity as defined by a Cq value of $=<35$ was $43.7 \%$ $(n=124)$ overall, while it was $33.7 \%(n=34)$ among healthy children while it was $49.2 \%(n=90)$ among the hospitalized children ( $p=0.013$, Chi-square test). Among these 284 participants, 117 (41.19\%) were detected to be colonized with pneumococci using culture-based method. The colonization rate by culture among healthy

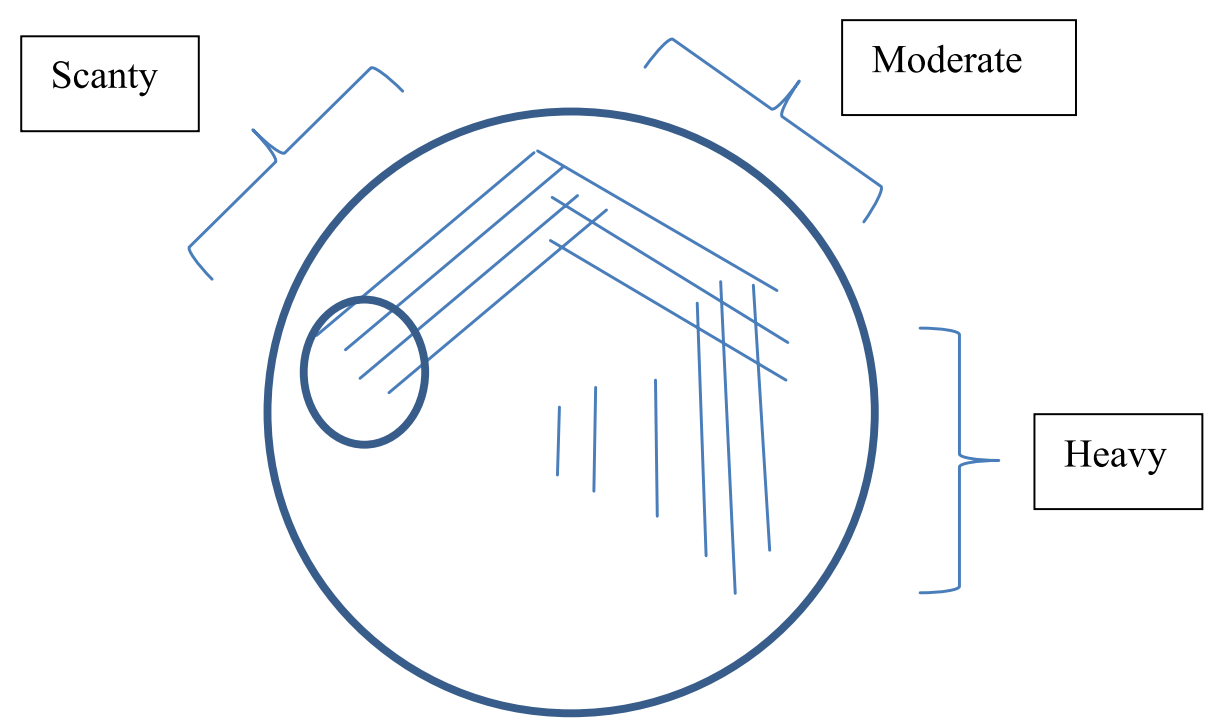

Fig. 1 Semi-quantitative colony count 
Table 1 Mean Cq values and the genomic copy numbers of the two study cohorts

\begin{tabular}{llll}
\hline Study cohort & Mean Cq value & $\begin{array}{l}\text { Mean Genomic DNA copy } \\
\text { number }\end{array}$ & Difference \\
\hline $\begin{array}{l}\text { Cohort A (Healthy babies from the immunization clinic) } \\
(n=101)\end{array}$ & $29.61 \pm 2.85$ & $\log 107.30 \pm 0.23$ & $p=0.354$, independent sample t test \\
Cohort B (Hospitalized babies cohort) $(n=183)$ & $28.93 \pm 3.62$ & $\log 107.49 \pm 1.07$ & \\
\hline
\end{tabular}

Table 2 Comparison of semi quantitative culture and RT-PCR results

\begin{tabular}{lll}
\hline Culture result & RT-PCR positive $(\mathbf{C q}=<\mathbf{3 5})(\mathbf{n = 1 2 4 )}$ & $\begin{array}{l}\text { RT-PCR negative } \\
(\mathbf{C q}>\mathbf{3 5})(\mathbf{n}-\mathbf{1 6 0})\end{array}$ \\
\hline No S. pneumoniae isolated $(n=167)$ & $21(12.6 \%)$ & $146(87.4 \%)$ \\
Heavy growth of S. pneumoniae isolated $(n=31)$ & $31(100 \%)$ & 0 \\
Moderate growth of S. pneumoniae isolated $(n=27)$ & $25(92.6 \%)$ & $2(7.4 \%)$ \\
Scanty growth of S. pneumoniae isolated $(n=59)$ & $47(79.7 \%)$ & $12(20.3 \%)$ \\
\hline
\end{tabular}

* Percentages given with the culture result as the denominator

children was $37.6 \%(n=38)$ while it was $43.2 \%(n=79)$ among the hospitalized children $(p=0.217$, Chi-square test).

Considering the RT-PCR positive samples, the mean Cq among healthy children was 29.61 (SD 2.85) while the mean Cq among the hospitalized children was 28.93 (SD 3.62). This difference was not statistically significant ( $p=0.328$, independent sample $\mathrm{t}$ test).

With the standard curve obtained from amplifying a dilution series of control DNA [21] the mean amount of genomic DNA copy numbers detected in children with respiratory symptoms was $\log _{10} 7.49$ (SD 1.07) while it was $\log _{10} 7.30$ (SD 0.23) in healthy children (Table 1). The difference was not statistically significant $(p=0.354$, independent sample $t$ test).

\section{Colonization by RT-PCR vs semi-quantitation on culture}

There were 21 participants with RT-PCR positivity where culture did not reveal a Streptococcus pneumoniae. There were also 14 participants where culture was positive for Streptococcus pneumoniae and RT-PCR was negative (Table 2). These 14 patients had yielded serotype 19F $(n=4), 6 \mathrm{~A}(n=2), 6 \mathrm{~B}(n=1), 11 \mathrm{~A} / \mathrm{D}(n=1), 9 \mathrm{~N} / \mathrm{L}$ $(n=1)$, cps and lytA negative isolates $(n=3)$ and cps negative but $L y t$ A positive isolates $(n=2)$ by culture.

\section{Identification of serotypes/serogroups and co-colonization} Of the 124 lytA RT-PCR positive samples, only 85 (68.5\%) were positive for the cps gene by conventional PCR targeting cps gene only. When the RT-PCR positive samples were tested with CDC1 multiplex PCR, only 54 (43.5\% of the samples yielded a cps band while 83 (66.9\%) samples yielded a cps band in the CDC 2 multiplex PCR. Moving only to serotyping results the following serotypes/groups
Table 3 Identification of the serotypes

\begin{tabular}{lll}
\hline Serotypes/groups & Frequency & Percentage \\
\hline Serogroup 6 & 18 & $14.5 \%$ \\
Serotype 19F & 7 & $5.6 \%$ \\
Serotype 14 & 5 & $4 \%$ \\
Serotype 9AN & 1 & $0.7 \%$ \\
Serotype 23F & 1 & $0.7 \%$ \\
\hline
\end{tabular}

were identified by direct PCR using $\mathrm{CDC} 1$ and $\mathrm{CDC} 2$ multiplexes (Table 3).

Co-colonization was found in 2 samples (serotype 23F - serogroup 6 and serotype 19F - serotype 14). We performed single PCR for serotype 19F and serogroup 6 on the samples that had positive cps signals in the single PCR. In that, 23 samples were found to be positive for serogroup 6 while 17 samples were positive for serotype 19F. Four samples were found to contain both serogroup 6 and serotype 19F. Due to limited amount of sample, further testing was not attempted.

\section{Discussion}

An overall colonization rate of $43.7 \%(124 / 284)$ was identified using the RT-PCR method among two groups of children aged between 2 months and 2 years in the present study. Healthy children had a colonization rate of $33.7 \%$ while children hospitalized with respiratory symptoms with or without fever had a colonization rate of $49.2 \%$. Colonization rate as detected by culture among the participants was $41.19 \%$. The higher colonization rate of the current sub-analysis is due to the higher sensitivity of the RT-PCR method. 
There are several other studies which have reported pneumococcal colonization using RT-PCR method. Courtney, Piralam. et al. [16] and Wyllie AL. et al. [26] have identified $82 \%$ and $69 \%$ pneumococcal colonization rates in healthy baby cohorts. In addition to that, Barameht P. et al. [27] and Niclas J. et al. [28] have identified $57.2 \%$ and $62 \%$ pneumococcal colonization rates among hospitalized children. This difference might be due to the time lapse, differences in socio-demographic backgrounds of participants, geographical differences, the specimens used in the studies or the age difference in the study groups. Further, we have used a cut off for considering RT-PCR positivity; this may have led some of the high $\mathrm{Cq}$ value positives with lower colonization density to be considered as not colonized with pneumococci.

A higher pneumococcal colonization density was observed in the hospitalized children cohort. Some previous studies have detected a higher pneumococcal colonization density in hospitalized children with respiratory symptoms and pneumococcal diseases [12, 15, 29, 30] while others have not [16].

Another study has evaluated the association of PCV immunization on the prevalence density of nasopharyngeal colonization by common, potentially pathogenic bacteria including S.pneumoniae [17]. They have observed a reduction in PCV7-serotype colonization which in turn had an impact on colonization prevalence and density of other bacterial species of the nasopharynx. However, none of our study population was vaccinated. As we did not have data on the final diagnosis of the patients or antibiotic use, we are unable to analyze the colonization density across disease categories or the effect of antibiotics on this result.

When comparing the conventional culture method and the RT-PCR method, LytA PCR was positivity rate was higher than culture positivity rate for Streptococcus pneumoniae in the hospitalized children cohort. This is expected given the sensitivity of the real time PCR assay [31]. However, there was a lower pneumococcal detection rate in the healthy baby cohort using the RT-PCR method than the conventional culture method. This might be attributed to the presence of lower colonization density leading to a lower concertation of DNA and the use of a Cq of 35 to define positivity. This highlights the need to carefully evaluate the interpretation used in detection of colonization with RT-PCR.

In addition to that, RT-PCR positivity correlated with semi quantitative culture, as demonstrated by others earlier [30].

A similar study has examined pneumococcal carriage dynamics, including density and multiple serotype carriage, in Indonesian infants during the first year of life [32]. The study has revealed an overall pneumococcal colonization rate of $22 \%$ by lytA RT-PCR. In addition to that, $6 \mathrm{~B}, 19 \mathrm{~F}, 23 \mathrm{~F}, 34$, and $15 \mathrm{~B} / \mathrm{C}$ were identified as the common serotypes using the microarray technique. The mean pneumococcal colonizing density of the study cohort was $6.04 \log 10 \mathrm{GE} / \mathrm{ml}$ which is slightly lesser than to the colonizing density of the present study. However, multiple serotype carriage was observed in 98 samples which are relatively higher than to our study. Further, the study has revealed that multiple serotype carriage was associated with the higher pneumococcal density. We attempted to identify the pneumococcal serotypes using conventional PCR, on the extracts that yielded pneumococci through RT-PCR and the attempt failed, due to the differences in sensitivities among the two methods. We could not perform RT-PCR based direct serotyping, therefore, it is difficult to comment conclusively on the co-colonization rates. However, we could state that any study that aims to detect co-colonization with molecular methods should use RT-PCR or another high sensitivity method such as microarray instead of conventional PCR This area needs further diagnostic evaluation in real-world setting due to the costs associated.

There are some limitations of the present study. Although, an attempt was made to detect co-colonization of different serotypes using the samples that were positive with lytA real time PCR, only conventional multiplex PCR was used due to limited funding. As the multiplex PCRs failed to yield the cps band in many of these samples, a single conventional PCR for cps locus was done for those samples. However, the positivity rate for this was also lower than for the real time PCR. Attempt to serotype directly using conventional multiplex PCRs gave unfavourable results. Use of single PCRs targeting the commonest serotypes identified by culture also gave rise to a relatively low positivity rate than expected based on culture isolate results. This is possibly due to the comparatively lower sensitivity rate of conventional PCR than real time PCR.

Although we have used lytA RT- PCR to identify pneumococci, certain other bacteria such as oral streptococci can harbor the S. pneumoniae lytA gene due to horizontal gene transfer [33]. Hence, a PCR technique with Spn9802- and Spn9828-specific primers, in combination with $l y t A$ - and ply-specific primers, has been recommended for identifying S. pneumonia [34].

Further, we did not have data on the clinical diagnosis of the patients with respiratory symptoms, therefore, a sub-analysis within this group could not be performed to identify any difference between the colonization densities in different disease groups. Further, we did not analyze the effect of antibiotic treatment on colonization density. 


\section{Conclusion}

In conclusion, present study revealed a higher pneumococcal colonization rate using the RT-PCR method comparing with the conventional culture method. In addition to that, a higher pneumococcal colonization density was reported in hospitalized children with respiratory symptoms which is in congruent with the previous studies, however the difference was not statistically significant unlike in some previous studies. Therefore, the use of quantitative RT-PCR along as a part of diagnostic algorhythms for aetiological diagnosis of pneumococcal diseases in children should be further evaluated. Further, we identified that the use of conventional PCR for direct serotyping on sample identified to contain pneumococci through RT-PCR, aiming to identify co-colonization is not an effective method.

\section{Abbreviations}

RT-PCR: Real Time Polymerase Chain Reaction; NPS: Nasopharyngeal swabs; WHO: World Health Organization; STGG: Skim milk, Tryptone, Glucose, and Glycerin; CDC: Centre for Disease Control and prevention; SBA: Sheep Blood Agar; ARI: Acute Respiratory IIInesses.

\section{Acknowledgements}

Not applicable

\section{Authors' contributions}

All authors meet universally accepted criteria for authorship and have read and agreed to the content being published. GV - Data collection, microbiological and molecular laboratory work, data base curation, analysis of data and writing up of paper ALSKA - participant recruitment, sample collection, microbiological laboratory work, primary work on database initiation and primary data analysis. TSM - sample collection, microbiological and molecular biological laboratory work, analysis of data. EWMAE - study design, sample processing, microbiological laboratory work, developing isolate storage process, curation of samples and interpretation of data. PH - RT-PCR optimization, interpretation of RT-PCR and analysis of data. STK - study design, participant recruitment, data analysis and interpretation. BND - study design, data analysis and interpretation. LVCL - study conceptualization, study design, microbiological and molecular laboratory work, database curation, data analysis, interpretation and drafting the paper.

\section{Funding}

Research grant WI216479 through Pfizer is acknowledged for financial assistance.

\section{Availability of data and materials}

Data are available from the corresponding author on reasonable request.

\section{Declarations}

Ethics approval and consent to participate

Ethics approval was obtained from the Ethia Review Committee, Faculty of Medicine, University of Peradeniya (2016/EC/63) and informed written consent was obtained from the guardians of the study participants. The study was conducted under the approved protocol following the international norms of ethics in human research.

\section{Consent for publication}

Not applicable

\section{Competing interests}

This study was funded by an investigator initiated grant to LVCL from Pfizer as mentioned below. However, they had no involvement in the data analysis or interpretation of data. GV, ALSKA, TSM, EWMAE, PH, STK and BND declare no conflicts of interest.

\section{Author details}

${ }^{1}$ Faculty of Medicine, University of Peradeniya, Kandy, Sri Lanka. ${ }^{2}$ Department of Microbiology, Faculty of Medicine, University of Peradeniya, Kandy, Sri Lanka. ${ }^{3}$ Department of Paediatrics, Faculty of Medicine, University of Peradeniya, Kandy, Sri Lanka.

Received: 14 June 2021 Accepted: 13 January 2022

Published online: 20 January 2022

\section{References}

1. Wahl B, O'Brien KL, Greenbaum A, et al. Burden of Streptococcus pneumoniae and Haemophilus influenzae type b disease in children in the era of conjugate vaccines: global, regional, and national estimates for 2000-2015. Lancet Glob Health. 2018;6(7):744-57. https://doi.org/10. 1016/S2214-109X(18)30247-X.

2. Brueggemann AB, Griffiths DT, Meats E, Peto T, Crook DW, Spratt BG. Clonal relationships between invasive and carriage Streptococcus pneumoniae and serotype-and clone-specific differences in invasive disease potential. J Infect Dis. 2003;187(9):1424-32. https://doi.org/10.1086/ 374624.

3. Gámez G, Rojas JP, Cardona S, Noreña JD, Palacio MA, Mejía LF, et al. Factors Associated with Streptococcus pneumoniae Nasopharyngeal Carriage and Antimicrobial Susceptibility among Children Under the Age of 5 Years in the Southwestern Colombia. J Pediatr Infect Dis. 2021;16(05):205-15. https://doi.org/10.1055/s-0041-173134.

4. Baggett HC, Watson NL, Deloria Knoll M, Brooks WA, Feikin DR, Hammitt $\mathrm{LL}$, et al. Density of upper respiratory colonization with Streptococcus pneumoniae and its role in the diagnosis of pneumococcal pneumonia among children aged $<5$ years in the PERCH study. Clin Infect Dis. 2017;64(3):S317-27. https://doi.org/10.1093/cid/cix100.

5. Thummeepak R, Leerach N, Kunthalert D, Tangchaisuriya U, Thanwisai A, Sitthisak S. J Infect Public Health. 2015;8(3):274-81. https://doi.org/10. 1016/j.jiph.2014.11.002 Pmid:25541228.

6. Marchisio P, Esposito S, Schito GC, Marchese A, Cavagna R, Principi N. Nasopharyngeal carriage of Streptococcus pneumoniae in healthy children: implications for the use of heptavalent pnemococcal conjugate vaccine. Emerg Infect Dis. 2002;8(5):479. https://doi.org/10.3201/eid0805. 010235.

7. Ueno M, Ishii Y, Tateda K, Anahara Y, Ebata A, lida M, et al. Prevalence and risk factors of nasopharyngeal carriage of Streptococcus pneumoniae in healthy children in Japan. Jpn J Infect Dis. 2013;66(1):22-5.

8. Immergluck LC, Kanungo S, Schwartz A, Mclntyre A, Schreckenberger PC, Diaz PS. Prevalence of streptococcus pneumoniae and staphylococcus aureus nasopharyngeal colonization in healthy children in the United States. Epidemiol Infect. 2004;132(2):159-66. https://doi.org/10.1017/ S0950268803001791.

9. Spellerberg B, Brandt C. Streptococcus. In: Murray PR, Baron EL, Jorgensen JH, Landry ML, Pfaller MA, editors. Manual of Clinical Microbiology. 9th ed. Washington DC: American Society for Microbiology; 2007. p. 412-29.

10. Davis TE, Fuller DD, Aeschleman EC. Rapid, direct identification of Staphylococcus aureus and Streptococcus pneumoniae from blood cultures using commercial immunologic kits and modified conventional tests. Diagn Microbiol Infect Dis. 1992;15(4):295-300. https://doi.org/10.1016/07328893(92)90014-K

11. Carvalho MG, Pimenta FC, Gertz RE Jr, Joshi HH, Trujillo AA, Keys LE, Findley J, Moura IS, Park IH, et al. PCR-based quantitation and clonal diversity of the current prevalent invasive serogroup 6 pneumococcal serotype, 6C, in the United States in 1999 and 2006 to 2007. J Clin Microbiol. 2009;47:554-9. https://doi.org/10.1128/JCM.01919-08.

12. Vu HTT, Yoshida LM, Suzuki M, et al. Association between nasopharyngeal load of Streptococcus pneumoniae, viral coinfection, and radiologically confirmed pneumonia in Vietnamese children. Pediatr Infect Dis J. 2011;30(1):11-8. https://doi.org/10.1097/INF.0b013e3181f111a2. 
13. Short KR, Reading PC, Wang N, Diavatopoulos DA, Wijburg OL. Increased nasopharyngeal bacterial titers and local inflammation facilitate transmission of Streptococcus pneumoniae. MBio. 2012;3(5):e00255. https://doi. org/10.1128/mBio.00255-12.

14. Baggett HC, Watson NL, Deloria Knoll M, Brooks WA, Feikin DR, Hammitt LL, Howie SR, Kotloff KL, Levine OS, Madhi SA, Murdoch DR. Density of upper respiratory colonization with Streptococcus pneumoniae and its role in the diagnosis of pneumococcal pneumonia among children aged $<5$ years in the PERCH study. Clin Infect Dis. 2017;64(3):S317-27.

15. Fan RR, Howard LM, Griffin MR, Edwards KM, Zhu Y, Williams JV, Vidal JE, Klugman KP, Gil Al, Lanata CF, Grijalva CG. Nasopharyngeal pneumococcal density and evolution of acute respiratory illnesses in young children, Peru, 2009-2011. Emerg Infect Dis. 2016;22(11):1996.

16. Piralam B, Prosperi C, Thamthitiwat S, Bunthi C, Sawatwong P, Sangwichian O, Higdon MM, Watson NL, Deloria Knoll M, Paveenkittiporn W, Chara C. Pneumococcal colonization prevalence and density among Thai children with severe pneumonia and community controls. PLoS One. 2020;15(4): e0232151. https://doi.org/10.1371/journal.pone.0232151.

17. Olwagen CP, Adrian PV, Nunes MC, Madhi SA. Evaluation of the association of pneumococcal conjugate vaccine immunization and density of nasopharyngeal bacterial colonization using a multiplex quantitative polymerase chain reaction assay. Vaccine. 2018;36(23):3278-85.

18. Bosch AA, van Houten MA, Bruin JP, Wijmenga-Monsuur AJ, Trzciński K, Bogaert D, Rots NY, Sanders EA. Nasopharyngeal carriage of Streptococcus pneumoniae and other bacteria in the 7th year after implementation of the pneumococcal conjugate vaccine in the Netherlands. Vaccine. 2016:34(4):531-9.

19. Vidanapathirana G, Angulmaduwa S, Munasinghe T, Ekanayake A, Kudagammana T, Dissanayaka N, Liyanapathirana V. Pneumococcal colonization among healthy and hospitalized vaccine-naive Sri Lankan children. Vaccine. 2020;38(46):7308-15. https://doi.org/10.1016/j.vaccine.2020.09.040.

20. Hassan-King M, Baldeh I, Secka O, Falade A, Greenwood B. Detection of Streptococcus pneumoniae DNA in blood cultures by PCR. J Clin Microbiol. 1994;32(7):1721-4. https://doi.org/10.1128/jcm.32.7.1721-1724.

21. Carvalho Mda G, Tondella ML, McCaustland K, Weidlich L, McGee L, Mayer LW, Steigerwalt A, Whaley M, Facklam RR, Fields B, Carlone G, Ades EW Dagan R, Sampson JS. Evaluation and improvement of real-time PCR assays targeting lytA, ply, and psaA genes for detection of pneumococcal DNA. J Clin Microbiol. 2007;45(8):2460-6.

22. Satzke C, Dunne EM, Porter BD, Klugman KP, Mulholland EK. The PneuCarriage Project: a multi-centre comparative study to identify the best serotyping methods for examining pneumococcal carriage in vaccine evaluation studies. PLoS Med. 2015;12(11):1001903. https://doi.org/10. 1371/journal.pmed.1001903.

23. Song JH, Lee NY, Ichiyama S, Yoshida R, Hirakata Y, Fu W, et al. Spread of drug resistant Streptococcus pneumoniae in Asian countries: Asian Network for Surveillance of Resistant Pathogens (ANSORP) study. Clin Infect Dis. 1999;28(6):1206-11. https://doi.org/10.1086/514783.

24. Satzke $C$, et al. Standard method for detecting upper respiratory carriage of Streptococcus pneumoniae: updated recommendation from the World Health Organization Pneumococcal Carriage Working Group. Vaccine. 2013;32:165-79. https://doi.org/10.1016/j.vaccine.2013.08.062.

25. Real-time PCR Identification of S. pneumoniae, pneumoniae detection spread sheet updated 2017, last accessed on 10/10/2019). https://www. cdc.gov/streplab/pneumococcus/resources.html?CDC_AA_refval= https\%3A\%2F\%2Fwww.cdc.gov\%2Fstreplab\%2Fprotocols.html,

26. Wyllie AL, Wijmenga-Monsuur AJ, Van Houten MA, Bosch AA, Groot JA, van Engelsdorp GJ, Bruin JP, Bogaert D, Rots NY, Sanders EA, Trzciński K. Molecular surveillance of nasopharyngeal carriage of Streptococcus pneumoniae in children vaccinated with conjugated polysaccharide pneumococcal vaccines. Sci Rep. 2016;6(1):1-9. https://doi.org/10.1038/ srep23809.

27. Smith-Vaughan H, Byun R, Nadkarni M, Jacques NA, Hunter N, Halpin S, Morris PS, Leach AJ. Measuring nasal bacterial load and its association with otitis media. BMC Ear, Nose and Throat Disorders. 2006;6(1):1-9. https://doi.org/10.1186/1472-6815-6-10.

28. Johansson N, Kalin M, Tiveljung-Lindell A, Giske CG, Hedlund J. Etiology of community-acquired pneumonia: increased microbiological yield with new diagnostic methods. Clin Infect Dis. 2010;50(2):202-9. https://doi. org/10.1086/648678.
29. Dhoubhadel BG, Yasunami M, Nguyen HA, Suzuki M, Vu TH, Nguyen AT, Dang DA, Yoshida LM, Ariyoshi K. Bacterial load of pneumococcal serotypes correlates with their prevalence and multiple serotypes is associated with acute respiratory infections among children less than 5 years of age. PLoS ONE. 2014;9(10): e110777. https://doi.org/10.1371/journal. pone.0110777.

30. Albrich WC, Madhi SA, Adrian PV, van Niekerk N, Mareletsi T, Cutland C, Wong M, Khoosal M, Karstaedt A, Zhao P, Deatly A, Sidhu M, Jansen KU, Klugman KP. Use of a rapid test of pneumococcal colonization density to diagnose pneumococcal pneumonia. Clin Infect Dis. 2012;54(5):601-9. https://doi.org/10.1093/cid/cir859.

31. Saravolatz LD, Johnson L, Galloway L, Manzor O, Pawlak J, Belian B. Detection of Streptococcus pneumoniae colonisation in respiratory tract secretions of military personnel. Clin Microbiol Infect. 2007;13(9):932-6. https://doi.org/10.1111/j.1469-0691.2007.01762.x Epub 2007 Jun 26. PubMed PMID: 17596202

32. Murad C, Dunne EM, Sudigdoadi S, Fadlyana E, Tarigan R, Pell CL, Watts E, Nguyen CD, Satzke C, Hinds J, Dewi MM. Pneumococcal carriage, density, and co-colonization dynamics: a longitudinal study in Indonesian infants. Int J Infect Dis. 2019;86:73-81. https://doi.org/10.1016/j.ijid.2019.06.024.

33. Seki M, Yamashita Y, Torigoe H, Tsuda H, Sato S, Maeno M. Loop-mediated isothermal amplification method targeting the lytA gene for detection of Streptococcus pneumoniae. J Clin Microbiol. 2005;43:1581-6. https://doi. org/10.1128/JCM.43.4.1581-1586.2005.

34. Park HK, Lee SJ, Yoon JW, Shin JW, Shin HS, Kook JK, Myung SC, Kim W. Identification of the cpsA gene as a specific marker for the discrimination of Streptococcus pneumoniae from viridans group streptococci. J Med Microbiol. 2010;59(10):1146-52. https://doi.org/10.1099/jmm.0.017798-0.

\section{Publisher's Note}

Springer Nature remains neutral with regard to jurisdictional claims in published maps and institutional affiliations.

Ready to submit your research? Choose BMC and benefit from

- fast, convenient online submission

- thorough peer review by experienced researchers in your field

- rapid publication on acceptance

- support for research data, including large and complex data types

- gold Open Access which fosters wider collaboration and increased citations

- maximum visibility for your research: over $100 \mathrm{M}$ website views per year

At BMC, research is always in progress.

Learn more biomedcentral.com/submissions 